\title{
ARSITEKTUR TRADISIONAL DI KASEPUHAN SINAR RESMI KABUPATEN SUKABUMI JAWA BARAT
}

\author{
TRADITIONAL ARCHITECTURE OF KASEPUHAN SINAR RESMI \\ IN SUKABUMI DISTRICT, WEST JAVA
}

\author{
Nandang Rusnandar \\ Balai Pelestarian Nilai Budaya Bandung \\ Jalan Cinambo No. 136 Ujungberung-Bandung 42094 \\ e-mail: nd_roes@yahoo.co.id
}

\begin{abstract}
Abstrak
Ketertarikan pada penelitian ini didasarkan pada adanya kesinambungan bentuk arsitektur tradisional di Tatar Sunda yang memiliki kesamaan dalam segi arsitektural, namun memiliki ciriciri mandiri yang disesuaikan dengan tata aturan dan adat istiadat setempat. Kampung Kasepuhan Sinar Resmi, merupakan salah satu kampung adat di wilayah Kecamatan Cisolok Kabupaten Sukabumi. Salah satu karya yang dihasilkan oleh komunitas ini adalah bentuk arsitektur yang merupakan cerminan kuat dari latarbelakang budaya yang melingkupinya. Simbol-simbol yang mengandung tata nilai menjadi acuan mereka dalam bergerak hidup, sehingga nilai-nilai itulah yang dapat mempertahankan keutuhan arsitektur. Tujuan penelitian ini adalah untuk mendapatkan gambaran secara utuh dan mendalam tentang arsitektur serta mengungkap simbol dan nilai filosofis masyarakatnya. Metode penelitian adalah metode kualitatif dengan teknik pengumpulan data berupa observasi langsung dan wawancara. Arsitektur, merupakan buah karya yang tak lepas dari simbol dan nilai yang melekat pada masyarakat pendukungnya, sehingga tata cara pembangunan tidak ditinggalkan walaupun perubahan terus melanda. Keteguhan dalam mempertahankan adat ini menjadi ciri mandiri dalam menghasilkan bentuk arsitektur yang ada di Sinar Resmi.
\end{abstract}

Kata kunci : arsitektur, adat istiadat, nilai-nilai.

\begin{abstract}
The interest in this research based on the relations between traditional architecture in Sudanese which have similarity in the shape of architecture, but they have a specific character adapted with the custom rules that they lived. Kasepuhan Sinar Resmi village is one of the traditional village in Cisolok sub-district, Sukabumi district. One of the works that they have made is the shape of architecture, it symbolize strong Sudanese character. The symbol which have values become a reference in facing their life, so that the values that can maintain the integrity of the architecture. The purposes of this research is to get the full picture and the depth of the architecture as well as revealing the symbol and the value of the philosophical community. The method of this research is qualitative, with direct observation and interview as a technique in collecting the data. Architecture as a masterpiece cannot separated from symbol and values in the society, so the procedures are not left even the changes continue to plague. Firmness in maintaining this custom became self-sufficient in generating characteristic architecture of Sinar Resmi village.
\end{abstract}

Keywords: architecture, customs, values. 


\section{A. PEN DAHULUAN}

Secara arsitektural, rumah-rumah tradisional menunjukkan usaha adaptasi dengan lingkungannya, sehingga letak, arah, dan bentuk sangat serasi, dengan mempertahankan tata aturan dan adatistiadat warisan budaya nenek moyang (Sumintardja, 1978:14). Di samping bentuknya, dapat pula dilihat dari pola perkampungan yang dicirikan dengan adanya aliran sungai, perkampungan terletak di lembah, pola perumahan yang mengelompok, semuanya menyerupai dengan kampung-kampung adat yang tersebar di wilayah budaya Sunda (Rusnandar, 2000: 4-5). Permukiman tradisional di Jawa Barat mempunyai sejumlah persamaan dan perbedaan, mengalami perubahan-perubahan, dan sedang mengalami tantangan akan kebertahanannya. Di sini bekerja kearifankearifan komunitas adat terhadap lingkungannya, yang menentukan apakah mereka dapat bertahan terhadap perubahan atau tidak (Belgawan, 2011:16).

Ada dua hal yang dapat dibedakan, yaitu antara rumah tradisional dan rumah adat; rumah tradisional adalah rumah yang apabila pembangunan dan aktivitasaktivitasnya didasarkan pada kebiasaan yang dijalankan secara turun-temurun walaupun dalam perjalanan waktu ada perubahan-perubahan dan dinamika. Dalam aspek mendirikan rumah atau unsur-unsur lainnya terutama dalam pelaksanaannya terdapat apa yang disebut pragmatika (the pragmatics), yaitu kebiasaan yang melekat di dalam menjalankan proses membangun suatu unsur bangunan. Sedangkan rumah adat, yaitu apabila pendirian rumahnya, selalu mengikuti aturan-aturan adat, bagaimana tata cara penggunaan bahan, perletakkan rumah, bentuk rumah, upacara-upacara, dan sebagainya. Aturan-aturan ini mengandung "sanksi", bisa yang kongkrit berupa sanksi adat, atau berupa tabu yang menyiratkan akibat-akibat apabila dilanggar. Namun demikian, di antara keduanya dengan sendirinya juga terdapat "tradisi" terkait dengan aktifitas mendirikan rumah/permukiman dan aktivitas bermukim pada umumnya, karena adanya aturan-aturan adat juga berarti mentradisikan hal-hal tersebut. Seorang pengamat arsitektur vernakular, Oliver (1987, 1997), dalam tulisannya menyebutkan bahwa arsitektur dari rumah yang tumbuh dan berkembang berdasarkan tradisi seperti ini adalah berkembang atas dasar tradisi "vernakular".

Rumah sebagai hasil cipta karya arsitektural, adalah cetusan ide yang diselaraskan dengan konteks alam yang dihadirkan dalam bentuk bangunan, baik dalam interior maupun eksterior. Jadi pengaruh lingkungan pada tatanan ruang dimana karya arsitektur didirikan sangat berperan terhadap pencetusan ide-ide dari sebuah desain arsitektur. Seperti halnya rumah tradisional, selain dibentuk dan dikomposisikan berdasarkan aturan adat juga berdasarkan bahan-bahan yang ada di alam. Mengutip dari Ballantyne (2002) bahwa 'domus', merupakan konsep rumah tradisional yang menunjukkan alam pedesaan, dimana semua yang dilakukan melayani alam, yaitu orang bekerja untuk mengolah tanah (alam) pedesaan. Hal ini bisa diartikan bahwa arsitektur rumah tradisional merupakan sebuah karya bangunan yang senantiasa mencerminkan budaya pedesaan yang umumnya berdasarkan konsep adat dalam tradisi membangun rumah.

Berbicara mengenai arsitektur tradisional, secara spesifik tidak lepas dari nilai-nilai budaya setempat. Dalam perkembangannya, arsitektur sebagai sebuah karya yang tak lepas dari pengaruh budaya luar, sehingga banyak karya arsitektur yang keluar dari unsur kedaerahannya. Berkaitan dengan hal tersebut, arsitektur tradisional Jawa Barat, khususnya arsitektur rumah di Kampung Kasepuhan Sinar Resmi Kabupaten Sukabumi perlu dilestarikan keberadaannya, hal tersebut disebabkan derasnya sentuh budaya yang dinamis yang 
memengaruhi bentuk-bentuk bangunan dari masa ke masa.

Kampung Kasepuhan Sinar Resmi, merupakan salah satu kampung adat yang berada di wilayah Jawa Barat tepatnya Kecamatan Cisolok Kabupaten Sukabumi, masyarakatnya masih teguh memegang adat-istiadat. Dengan demikian masyarakat ini bisa dikatakan sebagai komunitas adat yang kuat. Salah satu karya yang dihasilkan oleh komunitas ini ada dalam bentuk arsitektur, sehingga hasil yang dicapai dalam karyanya merupakan cerminan kuat dari latar belakang budaya yang melingkupinya. Buah karya masyarakat komunitas adat dalam bidang arsitektur, merupakan cerminan atau meminjam istilah sastra disebut mimesis kehidupan komunitas itu sendiri yang berkaitan erat dengan tempat ia berada. Maka pada hasilnya arsitektur merupakan hasil bentukan dan rupa bangunan yang terkait erat dengan lingkungan ia berada, untuk mengadaptasikan diri sesuai dengan pengalaman serta ide-idenya. Koentjaraningrat (1981:9) menyebutkan bahwa kebudayaan adalah keseluruhan gagasan dan karya manusia yang harus dibiasakannya dengan belajar, berserta keseluruhan dari hasil budi dan karyanya itu. Proses adaptasi antara manusia dan lingkungannya dicerminkan dalam cipta, rasa, dan karsa sehingga terlahir jiwa harmonis di antara keduanya. Manusia mengerti dengan sifat-sifat alamnya, sehingga alamnya akan memberi keseimbangan dalam keharmonisan yang terjaga. Hal tersebut terjadi karena pola pikir manusia pendukungnya selalu menyelaraskan dengan sifat alam yang ditempatinya.

Perubahan yang dirasakan dalam pembangunan, terus melanda hingga di pedesaan, khususnya di Kampung Kasepuhan Sinar Resmi, telah menyebabkan pergeseran terhadap wujudwujud kebudayaan yang terkandung dalam bentuk arsitektur tradisionalnya. Karya seni arsitektur kini lebih menonjol nilai artifisial dibanding nilai fungsionalnya, sehingga karya seni arsitektur itu kadangkadang bahkan malah sering tak bernada nilai kedaerahan. Sebagai contoh yang terjadi di Sinar Resmi sendiri, dewasa ini sudah muncul rumah yang bertembok dan beratap tidak lagi mempergunakan hateup, melainkan genting dan asbes.

Permasalahan yang muncul dalam penelitian ini adalah perubahan yang terjadi pada ciri arsitektural di Kampung Sinar Resmi, serta nilai-nilai yang terkandung dalam arsitektur.

Ruang lingkup daerah penelitian, yaitu Kasepuhan Sinar Resmi di Kabupaten Sukabumi yang merupakan salah satu Kampung Adat di Jawa Barat. Ruang lingkup penelitian, hal yang berkaitan dengan struktur bangunan, fungsi bangunan, bentuk bangunan dan nilai-nilai yang terkandung di dalamnya.

\section{B. METO DE PEN ELITIAN}

Arsitektur vernakular sering juga dikatakan sebagai 'setempat', 'primitif', 'asli', atau 'tradisional'. Akan terlihat, bahwa penyebutan 'primitif' yang seringkali dikaitkan dengan kesederhanaan yang dimiliki oleh bentuk suatu arsitektur menurut cara pandang kenvensional, banyak mengandung kesalahan. Vernakular artinya setempat (native), suatu arsitektur -apakah itu bangunan rumah atau yang lainnya, termasuk lingkungannya- adalah vernakular apabila memenuhi kriteria-kriteria yang terkait dengan lingkungan setempat, yaitu apabila pembentukannya terkait dengan lingkungan masyarakat tertentu dilihat dari penggunaan material, teknologi, aturan, dan sistem sosial atau sistem budayanya yang menghasilkan tradisi. Adanya peran tradisi dalam pembentukan dan pembangunan suatu arsitektur vernakular, menghasilkan kesamaan bentuk, sifat dan ekspresi dari rumah dan permukiman tersebut.

Walaupun arsitektur vernakular merujuk pada bentuk bangunan yang dibangun dari bahan lokal dan menggunakan teknologi setempat dengan 
cara yang sangat fungsional, di dalamnya terdapat ekspresi dan makna yang lebih fundamental. Rapoport (1990) menyatakan bahwa arsitektur menggambarkan bahwa rumah dan permukiman yang berbasis pada arsitektur vernakular adalah selalu merupakan hasil akumulasi dari berbagai alur konsepsi tentang unsur-unsur atau aspek-aspek rumah dan permukiman yang berkembang dari waktu ke waktu.

Turan (1990) menyatakan melalui bentuk rumah yang dihasilkan melalui alur-alur tersebut, arsitektur vernakular adalah hasil aktivitas dan upaya mencapai kesesuaian lingkungan ketimbang suatu pengetahuan yang diaplikasikan. Aktivitasnya merupakan cara untuk merespon kondisi yang ada, memenuhi kebutuhan-kebutuhan lingkungan tertentu bagi sekelompok tertentu manusia atau suatu komunitas tertentu.

Bahkan lebih jauh lagi, arsitektur vernkular umumnya mengandung bentuk (embodies) nilai-nilai suatu komunitas, bahkan menyimbolkan konsep kosmos, atau bertindak sebagai suatu analogi untuk suatu abstraksi kepercayaan tertentu. Oleh karena itu, bahkan suatu rumah atau hunian yang sederhana dalam suatu tradisi vernakular, mungkin merefleksikan suatu dunia material dan spiritual dari pembangun atau penghuninya (Oliver, 1997). Walaupun demikian, ciri-ciri ideal ke-vernakular-an dari suatu arsitektur tidak dapat ditentukan. Hal yang bisa dilakukan adalah melihat apakah sesuatu arsitektur lebih vernakular dari yang lain atau tidak (Rapoport, 1990). Oleh karena itu, tradisi vernakular (dapat) berbeda dari suatu tempat ke tempat lain atau dari suatu masyarakat ke masyarakat lain yang merupakan hasil adaptasi dan perubahan sejalan dengan waktu dan lingkungannya.

Banyak permukiman berdasar tradisi vernakular yang dimiliki komunitas yang memiliki suatu ekspresi budaya tertentu dengan tatanan atau pola memusat, yaitu pendirinya. Maka untuk menunjukkan adanya bagian yang sakral, yaitu inti tadi, dapat pula menunjukkan adanya struktur kekuasaan di permukiman tersebut, baik yang ditunjukkan kepada pendiri pemukiman, tokoh spiritual yang terletak pada inti tadi (Egenter, 1991).

Konsep pola memusat seperti ini merupakan cara untuk mengharmoniskan pengaturan atau penataan buatan lingkungan alamnya. Di samping itu menggambarkan pula hirarki sosial, pusat pemukiman merupakan tempat bagi perintis atau pendiri permukiman yang bisa menjadi 'penguasa' lokal atau tokoh spriritual tertinggi di dalam permukiman tersebut. Penataan itu pula mengindikasikan proses pembentukan permukiman, komunitas agraris, proses ritual religi, pembentukan mikro kosmos dan hirarki sosial yang menggambarkan pemusatan dari sistem budaya masyarakat agraris.

Dapat dicatat bahwa arsitektur tradisional, arsitektur pemukiman adat (vernakular) adalah suatu proses dan produk (hasil) yang sarat makna. Dengan melihat dan membaca bentuk arsitektur ini kita dapat memahami makna-makna yang terkandung di dalamnya.

Penelitian ini dilakukan dengan tiga cara, yaitu: (1) observasi partisipasi (participant observation), (2) wawancara mendalam (in-depth interview), dan (3) penggunaan dokumen (dokument used). Teknik observasi partisipasi. Partisipan bertindak sebagai pengamat aktif dengan menyaksikan dan mengikuti kegiatan yang dilakukan, mencatat dan melakukan tanya jawab dengan informan, kemudian dilanjutkan dengan analisis secara cermat tentang apa yang telah diamati tersebut. Wawancara terbuka atau mendalam, yang memberi keleluasaan bagi informan untuk memberi pandangan-pandangan secara bebas (Koentjaraningrat, 1989: 30). Wawancara demikian ini memungkinkan si peneliti untuk mengajukan pertanyaanpertanyaan secara mendalam. Karena itu, untuk melengkapi data penelitian ini, khususnya dalam upaya memperoleh data yang akurat tentang penelitian ini, peneliti melakukan wawancara dengan informan. 
Dalam penelitian ini, wawancara yang akan digunakan adalah wawancara yang mendalam atau wawancara tak berstruktur. Wawancara tak berstruktur mirip dengan percakapan informal (Mulyana, 2001: 181). Wawancara jenis ini dilakukan karena bersifat luwes, susunan pertanyaan atau kata-kata dapat diubah saat wawancara dilaksanakan, disesuaikan dengan kebutuhan, dan kondisi informan yang dihadapi.

Penelitian ini kurang lengkap jika hanya menggunakan teknik pengumpulan data dengan non-partisipation observation dan in-depth interview. Oleh karena itu, peneliti juga menggunakan teknik dokumentasi. Hal ini dilakukan dengan menganalisis beberapa dokumen seperti buku-buku, hasil penelitian, jurnal, berita koran, artikel majalah, buletin, foto-foto, tulisan-tulisan ilmiah dan bahan-bahan bacaan lainnya yang berhubungan dengan penelitian ini.

\section{HA SIL DAN BAHASA N}

Kasepuhan Sinar Resmi adalah sebuah kampung adat yang mempunyai ciri khas adat istiadat, bentuk rumah serta tradisi yang masih dipegang kuat oleh masyarakat pendukungnya. Masyarakat yang tinggal di Kasepuhan Sinar Resmi disebut masyarakat kasepuhan. Istilah kasepuhan berasal dari kata sepuh ditambah dengan awalan / ka-/ dan akhiran /-an/ bermakna menunjukkan tempat. Dalam bahasa Sunda, kata sepuh berarti 'kolot' atau tua dalam bahasa Indonesia. Berdasarkan pengertian ini, muncullah istilah kasepuhan, yaitu tempat tinggal para orang tua. Sebutan kasepuhan ini pun menunjukkan model 'sistem kepemimpinan' dari suatu komunitas atau masyarakat yang berasaskan adat kebiasaan para orang tua (sepuh atau kolot). Kasepuhan berarti 'adat kebiasaan orang tua' atau 'adat kebiasaan nenek moyang'. Menurut Anis Djatisunda (1984), nama kasepuhan hanya merupakan istilah atau sebutan orang luar terhadap kelompok sosial ini yang pada masa lalu kelompok ini menamakan dirinya dengan istilah keturunan Pancer Pangawinan. Pada era 1960-an, Kampung Kasepuhan Sinar Resmi mempunyai nama khusus yang dapat dianggap sebagai nama asli masyarakat tersebut, yaitu Perbu. Nama perbu kemudian hilang dan berganti menjadi kasepuhan atau kasatuan. Selain itu, mereka pun disebut dengan istilah masyarakat tradisi.

Permukiman yang ada di Sinar Resmi hampir sama dengan pola pemukiman masyarakat adat yang ada di daerah Sukabumi Selatan, yaitu pola permukiman yang mengelompok dengan membangun rumah di badan perbukitan, sehingga menempatkan rumahnya di tempat lahan yang berkontur. Tata letak bangunan rumah tampak teratur. Sinar Resmi merupakan pusat kasepuhan, di dalam kawasan Kampung Sinar Resmi terdapat 111 kepala keluarga dan sebagian penduduk atau warganya tersebar di berbagai kampung kecil yang terdiri atas 10-30 rumah, yang membentuk babakan (perkampungan), pola perkampungan (the farm village type) dengan pusat kota sebagai perkampungan terbesar (Smith dan Zopf, 1970). Babakan (perkampungan) itu dibentuk dalam satu keluarga besar, setiap pola perkampungan ini biasanya dihubungkan oleh akses jalan setapak.

Menurut Vitruvius, dalam bukunya De Architectura Libri $X$ (merupakan sumber tertulis paling tua), bangunan yang baik haruslah memiliki keindahan/estetika (venustas), kekuatan (firmitas), dan kegunaan/fungsi (utilitas). ${ }^{1}$ Arsitektur dapat dikatakan sebagai keseimbangan dan koordinasi antara ketiga unsur tersebut, dan tidak ada satu unsur yang melebihi unsur lainnya. Dalam definisi modern, arsitektur harus mencakup pertimbangan fungsi, estetika, dan psikologis. Namun, dapat dikatakan pula bahwa unsur fungsi itu sendiri di dalamnya sudah mencakup baik unsur estetika maupun psikologis.

\footnotetext{
${ }^{1}$ http://www.vitruvius.be
} 
Arsitektur adalah bidang multidispilin, termasuk di dalamnya adalah matematika, sains, seni, teknologi humaniora, politik, sejarah, filsafat, dan sebagainya. Mengutip pendapat Vitruvius, "Arsitektur adalah ilmu yang timbul dari ilmu-ilmu lainnya, dan dilengkapi dengan proses belajar: dibantu dengan penilaian terhadap karya tersebut sebagai karya seni". Ia pun menambahkan bahwa seorang arsitek harus fasih di dalam bidang musik, astronomi, filsafat --adalah salah satu yang utama di dalam pendekatan arsitekturBahwa seni dalam kaitannya dengan arsitektur adalah sebuah karya yang berhubungan dengan gagasan ruang yang dibagi dalam dua kategori; yaitu Filledspace installation atau Site-specific installation yang diterapkan pada ruang interior maupun eksterior arsitektur dan berpengaruh terhadap perilaku manusia (pengalaman berkesenian). Alam merupakan ruang tidak terbatas yang senantiasa berpengaruh terhadap kehidupan perilaku manusia yang berpengaruh terhadap keberadaan arsitektur dan seni instalasi. (merupakan sebuah bidang keilmuan yang berurusan dengan kreatifitas manusia). Hal ini berhubungan dengan masalah 'estetika' pada sebuah teknik pengetahuan yang disebut desain dan berhubungan dengan masalah penciptaan, merancang, dan proses berkarya, mulai dari ide, memilih, menyusun, mengolah serta membentuk.

Sebagai unsur kebudayaan, arsitektur selalu merupakan sekelompok pola dan bentukan baku yang merupakan pantulan sikap budayanya. Pola dan bentukan ini sama sekali tidak statis namun selalu berubah, menyesuaikan diri dengan perjalanan sejarah dan pengalaman budaya; baik individu maupun kelompoknya. Keterikatan pada pola, jauh lebih erat daripada keterikatan pada bentukan, bahan, dan teknologi. Wujud ideal yang tertanam pada dunia bawah sadar ini membutuhkan waktu jauh lebih lama untuk berubah dan justru sisi ini yang sering dilupakan.

\section{Rumah Tradisional: Rumah Tempat Tinggal}

Rumah di Kasepuhan Sinar Resmi dikenal dengan istilah imah atau dalam bahasa halusnya disebut bumi. Rumah dibedakan dalam dua macam bentuk atap yang menjadi ciri rumah-rumah di Kasepuhan Sinar Resmi, yaitu bentuk atap jingjing regis dan julang ngapak. Bentuk atap jingjing regis atau umumnya disebut suhunan jolopong yang memiliki ciri atap curam di kedua sisinya. Jenis atap ini merupakan bentuk atap asli rumah di Kasepuhan Sinar Resmi. Sedangkan atap jenis julang ngapak merupakan pengembangan dari bentuk atap jingjing regis dengan penambahan semacam sorondoy pada salah satu sisinya, sehingga menyerupai sayap burung julang. Atap ini kemudian disebut julang ngapak.

Dilihat dari jenis tiang yang dipergunakannya ada dua macam rumah, yaitu rumah dengan tiang yang langsung, sebagai penyangga di bawahnya mempergunakan umpak dari batu lempar (batu ceper) dan imah gagalur yaitu rumah yang penyangganya mempergunakan tatapakan jangkung terbuat dari batu cadas yang dicetak.

Perkembangan arsitektur rumah di Kasepuhan Sinar Resmi dipelopori oleh Abah Ujat dan diteruskan oleh Abah Asep pada tahun 2002. Pembangunan diawali ketika Imah Gede dibangun kembali atau 'ngarehab' di atas lelemah (tanah bekas rumah lama). Perubahan Imah Gede, dewasa ini sudah mempergunakan jendela kaca, lantai yang tadinya dominan talupuh, kini hanya bagian dapurnya saja, sedangkan ruangan lain berlantai papan yang diserut rapih. Menurut Abah Asep, perubahan ini tidak melanggar pamali (tabu) yang ditentukan adat, karena tidak mengubah tempat dapur dengan elemennya seperti ruang goah, pangdaringan, parako, talupuh, dan dapur.

Perubahan yang dilakukan oleh Abah Asep Nugraha sebagai sesepuh Kampung Sinar Resmi itu, kemudian diikuti oleh semua penduduk yang misepuh 
kepadanya. Perubahan yang terjadi dalam pembangunan dan tampilan rumah secara fisik sangat jelas terlihat, rumah-rumah telah memiliki jendela kaca, lantai (tataban) di tengah rumah mempergunakan tataban dari papan sedangkan tataban dari talupuh (lembaran bambu yang dibelah kecil-kecil) hanya dipergunakan di dapur saja. Adanya penambahan ruangan kamar tidur, bilik di bagian depan rumah diganti dengan bilahan papan, bahkan ada yang mempergunakan atap genting dan asbes, dan ada beberapa rumah yang memiliki loteng (berlantai dua). Perubahan yang lebih signifikan, yaitu rumah tidak saja mempergunakan material kayu, melainkan sudah mempergunakan adukan semen, seperti layaknya rumah gedung yang ada di luar Kasepuhan Sinar Resmi.

Begitu pula yang terjadi terhadap pelaburan dinding rumah atau bilik, ada yang 'dikapur' atau dilabur dengan kapur berwarna putih seluruhnya atau dikapur hanya bagian-bagian tertentu saja dan ada pula yang mempergunakan cat berwarna pada bagian-bagian tiang atau kusen pintu dan kusen jendela di depan rumah. Abah Asep tidak menyetujui dengan pelaburan dan pemakaian cat berwarna ini, karena menurutnya rumah harus warna alami. Sejatinya rumah adalah gambaran hidup seadanya.

Perubahan lainnya yaitu fungsi kolong. Pada awalnya kolong rumah memiliki ketinggian yang cukup tinggi, karena kolong rumah berfungsi sebagai kandang ternak. Sesuai dengan falsafah yang ada mengenai kolong, yaitu kolong kudu sadungkuk sanagog, supaya katurut ku hayam (tingginya kolong harus setinggi orang berjongkok, agar ayam dapat hidup bersama). Falsafah itu menunjukkan pengertian bahwa ayam adalah hewan yang paling dekat dengan kehidupan manusia. Suara ayam menjadi penentu waktu yang pasti, dengan suara kokokannya yang nyaring pada waktu subuh dapat memberitahukan kepada umat manusia bahwa hari sudah menjelang siang, cepat bangun untuk menjemput rezeki. Begitu pula dalam berbagai acara adat, ayam menjadi hal yang penting, karena ayam dijadikan simbol jiwa dan kehidupan manusia. Seperti apa yang dikatakan Abah: "Sagala ge kudu dihuripan ku hayam" (semuanya harus diberi jiwa oleh ayam).

Seiring dengan perubahan yang dilakukan Abah Asep mengenai kesehatan bagi manusia yang harus dijaga dengan benar, maka fungsi kolong dewasa ini hanya dijadikan sebagai tempat penyimpanan alat-alat pertanian, penyimpanan kayu bahan bangunan atau penyimpanan kayu bakar. Hal ini menyebabkan pembuatan tinggi kolong (baik yang disangga dengan mempergunakan batu lempar maupun tatapakan) umumnya seragam berkisar antara 40 sampai dengan $50 \mathrm{~cm}$ dari atas tanah.

Tiang-tiang rumah ditempatkan di atas batu yang lempar atau 'ceper, rata' yang disebut umpak. Sedangkan tatapakan merupakan batu cadas yang dicetak menyerupai bentuk limas dengan ukuran yang sama, yaitu tinggi $40 \mathrm{~cm}$ dan lebar bawah $30 \times 30 \mathrm{~cm}$ dan lebar atas $20 \mathrm{x}$ $20 \mathrm{~cm}$. Untuk mendapatkan batu tatapakan ini biasanya mereka memesan atau membeli dari luar kampung (Kampung Cicadas). Umpak terbuat dari batu bongkahan biasa yang besarnya kirakira berdiameter $30 \mathrm{~cm}$ dapat dicari dan diambil dari batu-batu yang terhampar di Sungai Cibareno yang tidak jauh dari kampung atau daerah sekitar.

Rumah berfungsi sebagai tempat berbagai macam kegiatan kehidupan sehari-hari, menuntut perlakuan yang sangat hati-hati berdasarkan aturan adat istiadat yang berlaku di Kasepuhan Sinar Resmi. Namun dalam perkembangannya aturan-aturan itu tidak lantas menjadi aturan kaku yang tidak dapat berubah sehingga mengikat masyarakatnya dalam menghadapi pengaruh modernisasi dan teknologi baru. Hal ini berlaku pada sistem tekonologi yang dipergunakannya. Pada awalnya teknologi yang dipergunakan 
dalam pembangunan rumah khususnya dalam membuat rangki atau rangkay (struktur kayu) sangat sederhana. Hubungan antara batang kayu yang satu dengan yang lainnya tidak mempergunakan paku, mereka hanya mempergunakan pen atau paseuk (paku yang terbuat dari bambu atau kayu). Kini untuk memperkuat hubungan kayu, mereka telah mempergunakan paku besi. Menurut cerita seorang tukang bas (ahli bangunan), dahulu untuk memperkuat hubungan kayu ini mempergunakan tali rotan, tali injuk atau tali dari bambu.

Rangka rumah pada umumnya terbuat dari kayu yang didapatkan dari kebun di luar hutan larangan, tempatnya jauh dari perkampungan dan Taman Nasional Hutan Gunung Halimun. Pengertian mengenai hutan atau leuweung, mereka mengenal adanya leuweung tutupan, leuweung titipan, leuweung cawisan, dan leuweung garapan. Leuweung tutupan adalah hutan yang tidak boleh diganggu sedikitpun, sehingga keadaan hutan ini sangat perawan. Leuweung titipan adalah hutan yang masih dapat diganggu apabila dalam keadaan terpaksa, misalnya tidak ada lagi kayu yang dapat diambil dari leuweung cawisan untuk kepentingan adat atau membuat rumah. leuweung cawisan adalah hutan yang sudah diperuntukkan bagi masyarakat, sehingga hutan ini merupakan hak masyarakat sehingga dapat dijadikan permukiman. Leuweung garapan adalah hutan yang dapat dikerjakan demi kebutuhan seluruh masyarakat, baik untuk keperluan sehari-hari maupun keperluan adat.

Rumah yang dahulu hanya berjendela satu dan tidak menggunakan kaca, kini dengan kesadaran yang diberikan oleh Abah Asep mengenai kesehatan dan sirkulasi udara, rumahrumah telah menggunakan banyak jendela dan berkaca. Perubahan ini pun berpengaruh pada kebutuhan akan perabot rumah tangga, mereka telah pula memiliki barang-barang elektronik seiring dengan masuknya jaringan listrik seperti kulkas, kompor gas, ranjang dan lemari. Bahkan peralatan elektronik seperti TV, handphone, radio, parabola, yang menjadi pola hidup modern. Apabila dihitung jumlah penduduk yang telah memiliki parabola, sebanyak 17 buah. Hal ini menunjukkan bahwa informasi dan hiburan telah menjadi kebutuhan yang harus dipenuhi.

Proses adaptasi dibarengi dengan kearifan manusianya agar kehidupan harmoni terjalin antara manusia dan alamnya. Proses adaptasi manusia dengan alamnya merupakan keharmonisan dan keselarasan yang harus terus dijaga, sehingga hubungan yang harmonis ini menyebabkan manusia dan alamnya menghasilkan keselarasan dan keseimbangan hidup. Hal tersebut dapat dilihat dari segi arsitektural rumah yang sangat adaptif dengan alam sekitarnya. Pembuatan atap dari hateup dan injuk, jenis atap yang berbentuk julang ngapak adalah proses adaptif manusia untuk menyelaraskan diri dengan alam lingkungannya agar manusia terjaga dari rasa dingin. Atap yang terbuat dari genting sangat ditabukan, karena apabila ada rumah yang mempergunakan genting dikatakan paeh samemeh paeh (sudah mati sebelum mati). Maksudnya atap dari genting (terbuat dari tanah) menunjukkan pengisi rumahnya sama dengan orang yang sudah mati dikubur. Untuk kekokohan halaman yang berkontur di lembah, dengan kearifannya diperlukan keahlian membuat benteng yaitu menata batu untuk menyangga tanah agar tidak terjadi longsor.

Penduduk Sinar Resmi, tidak semuanya merupakan seuweu/ulun kumawula kepada Abah, melainkan ada warga yang menjadi seuweu/ulun kumawula pada Kasepuhan Cipatamulya atau Kasepuhan Ciptagelar. Hal ini berdampak pada kebijakan dalam membangun rumah yang tidak perlu meminta izin kepada Abah Asep (Sinar Resmi), melainkan kepada Kasepuhan 
Ciptamulya atau Ciptagelar. Sehingga tidak semua rumah merupakan rumah panggung.

Rumah warga yang menjadi seuweu/ulun kumawula kepada Abah Asep (Sinar Resmi) yang ada di Kampung Sinar Resmi semuanya panggung dengan konstruksi rangka, yang menumpu pada tatapakan dan umpak. Rumah-rumah yang telah direhab hampir semuanya bertumpu atau ditopang tatapakan jangkung atau batu citak, berbentuk limas terpancang ukuran bawah $30 \times 30 \mathrm{~cm}$ bagian atas 20x20 $\mathrm{cm}$, tinggi sekitar $40 \mathrm{~cm}$. Jarak antara tiang bergantung pada panjangnya rumah. Atap rumah berbentuk julang ngapak, di bagian depan ada penambahan atap kecil yang landai, atap ini disebut atap wangkilas atau kerepes (Adimiharja, dkk 1996:33 dan 81). Kontruksi lantai terdiri atas balok kayu, yang menyangga kerangka dinding disebut gagalur, yang menyangga lantai disebut pananggeuy, balok anak disebut darurung terbuat dari bambu.

Hiasan di atas atap rumah pada setiap perkampungan adat di Jawa Barat, memiliki ciri khas tersendiri, yaitu pada setiap ujung atap bagian depan dan belakang wuwung (bubungan) selalu ditambahkan pamantes 'aksentuasi', yaitu adanya penambahan usuk yang terbuat dari bilah bambu atau kayu sepanjang $50 \mathrm{~cm}$ dibentuk menyerupai huruf "V" yang disebut gapit, cagak gunting atau capit hurang (Adimihardja, 1981 : 17). Namun khusus di Kampung Sinar Resmi pamantes itu berbentuk bulat, yang divariasikan dengan balutan tali ijuk yang dijalin agar tidak masuk air hujan, hingga menyatu dari ujung ke ujung yang membentuk huruf "O" yang disebut geulang 'gelang'.

Bentuk gapit, cagak gunting, capit hurang, ataupun geugeulang. semuanya memiliki makna simbolis. Huruf "V" (cagak gunting dan capit hurang) memiliki makna memasuki dunia atas yang suci, sementara manusia berada di dunia tengah. Huruf " $\Omega$ " (bentuk abig) merupakan gambaran dunia tengah yaitu rumah secara keseluruhan yang dihuni oleh manusia, sedangkan dunia bawah berada di dalam tanah yang dihuni oleh makhluk lainnya. Kebiasaan memakai gapit, cagak gunting, atau capit hurang ini sesuai dengan kepercayaan megaliticum yang disesuaikan dengan peredaran matahari dari arah timur ke barat dan sesuai pula dengan arah memanjangnya arah rumah timur barat (Adimihardja, 1981: 17.) Rusnandar, menyatakan bahwa pemaknaan huruf "O" atau geulang merupakan simbol ikatan kesatuan dalam kepercayaan mereka terhadap alam semesta dengan segenap isinya, di mana matahari bergerak dari timur ke barat (2010:20). Sedangkan, menurut penuturan Abah Asep dan tukang bas, bentuk "O" ini memiliki makna kebulatan tekad antara kepercayaan manusia terhadap Tuhannya. Bentuk "O" artinya dibelengkungkeun kudu yakin kanu boga-Na (dibulatkan, harus yakin benar kepada yang Empunya/Tuhan) atau ngabuleudkeun anu tilu, nya eta ucap, tekad jeung lampah (membulatkan ketiga unsur yaitu perkataan, tekad, dan perilaku). Menurut pandangan budayawan, pengertian rumah adalah:

".... Rumah itu Omah, omah itu dari kata $\mathrm{Om}$ dan mah, Om artinya "O", maknanya langit, maksudnya ruang, bersifat jantan. Mah artinya menghadap ke atas, maknanya bumi, maksudnya betina. Jadi rumah adalah ruang pertemuan laki dan rabinya. Karenanya kupanggil kau Semah, karena kita serumah. (YB.Mangunwijaya).

Atap genting dan asbes dipergunakan setelah terjadinya kebakaran yang menimpa kampung kira-kira pada tahun 2004. Pada waktu itu ada bantuan dari pemerintah yang menyeragamkan material banguan rumah. Masyarakat pun akhirnya menerima dengan kearifannya sendiri, sehingga yang terjadi adalah atap genting ditutupi dengan lembaran ijuk. Namun untuk ruang tertentu, misalnya pangdaringan, mereka tetap mempergunakan hateup dan ijuk.

Bentuk " $\Lambda$ " (bentuk abig) atau "V" terbalik dan bentuk "O", secara fisik 
adalah rumah (bumi/imah), namun dalam kosmologisnya adalah simbolisasi dunia tengah yang ditempati manusia, penghubungnya antara dunia tengah dan dunia atas adalah dunia hampa yang disebut para 'ruang di atas plapon dan hateup' (Suhamihardja, 1991/1992:49). Ruang belakang atau dapur lebih dominan adalah kaum wanita, apalagi yang berhubungan dengan pangdaringan tempat "Nyi Sri" berada, itu merupakan wilayah sakral bagi kaum wanita, kaum laki-laki tabu untuk memasukinya.

Secara kosmologis, konsep imah memiliki arti yang sama, yaitu rumah (bahasa Indonesia), dalam pemaknaannya yang menunjuk pada arti 'dunia' atau alam semesta. Dalam kepercayaan masyarakat Sunda (kosmologis Sunda) umumnya dikenal konsep pembagian dunia menjadi tiga bagian, yaitu dunya handap, dunya tengah dan dunya luhur "(dunia bawah, dunia tengah, dan dunia atas). Kenyataan ini dapat dilihat dari tata ruang dalam rumah, yaitu ruang depan atau tepas, ruang tengah atau tengah imah dan ruang belakang atau dapur, goah dan pangdaringan. Ruang depan merupakan ruangan untuk menerima tamu dan dipergunakan sekali-kali. Ruang tengah merupakan tempat kegiatan semua keluarga karena ruang ini disebut pula daerah bebas atau netral. Ruang tengah dapat dianalogikan sebagai dunia tengah, karena dunia tengah merupakan pusat alam semesta dan manusia menempatkan dirinya di pusat alam semesta.

\section{0 rganisasi Rumah}

Organisasi rumah merupakan penempatan ruang-ruang yang ada pada setiap imah yang ada di Kasepuhan Sinar Resmi, sehingga setiap rumah memiliki kesamaan yang hampir seragam dalam penempatan ruang-ruangnya. Dalam pengorganisasian ruang-ruang dalam rumah pun harus ditaati selaras tata aturan tatali karuhunnya, walaupun perubahan demi perubahan terus terjadi dan berlanjut dari hari ke hari. Namun ketentuan sangat diperhatikan oleh masyarakat Kasepuhan Sinar Resmi. Seperti yang pernah diucapkan Abah Asep "Boleh terjadi perubahan tapi hal-hal pokok tidak boleh dirempak atau 'dilanggar'.

Masyarakat Kasepuhan Sinar Resmi yang sangat mempercayai adanya $N y i$ Pohaci Sang Hyang Sri Dangdayang Tisnawati 'Dewi Sri' sebagai pengayom tanaman padi, maka hal tersebut tidak lepas dengan penempatan dapur dan goah yang erat kaitannya dengan kosmologis wilayah wanita -khusus goah, yang tidak boleh dimasuki kaum pria- sangat dominan bagi masyarakat Kasepuhan Sinar Resmi, malah fungsinya dapat mengalahkan fungsi kamar tidur sekalipun. Goah diletakkan di dapur sebelah barat atau timur sesuai dengan weton atau hari kelahiran dari yang punya rumah, yaitu weton si istri. Di dalam goah inilah disajikan berbagai sesaji untuk menghormati Dewi Sri.

\section{Rumah A dat: Imah Gede}

Sebuah rumah yang dianggap suci bagi masyarakat Kasepuhan Sinar Resmi, dan secara adat ditempatkan pada posisi yang luhur dan juga memiliki nilai khusus adalah Imah Gede. Imah Gede merupakan tempat tinggal khusus Abah Asep sebagai tutunggul atau kasepuhan yang dituakan di kampung itu. Abah Asep Nugraha diangkat menjadi tutunggul pada tanggal 2 Februari 2002 Di tempat ini pula musyawarah antarwarga Kasepuhan Sinar Resmi dilaksanakan. Di samping itu, Imah Gede biasa pula dipergunakan sebagai tempat untuk menerima berbagai tamu yang datang ke Kasepuhan Sinar Resmi. Biasanya tamu yang datang dan diterima di sini adalah tamu-tamu dari pemerintah seperti tamu dari kabupaten, provinsi, atau pun dari berbagai daerah lainnya, di samping incu putu Kasepuhan Sinar Resmi sendiri.

Imah Gede sebagai sebuah tempat pertemuan dan musyawarah juga sekaligus tempat penerimaan tamu, merupakan elemen yang tak dapat dipisahkan dengan 
karakteristik Kasepuhan Sinar Resmi secara keseluruhan, karena Imah Gede dapat dikatakan memiliki ciri khas yang tak dapat dipisahkan dari elemen lainnya, yaitu Saung Panyayuran, Saung Pakemitan, Ajeng, lapangan, dan Leuit Si Jimat. Kelima elemen khas ini merupakan fasilitas untuk memenuhi kebutuhan sosial dan ritual dalam waktu-waktu tertentu dilakukan di Kasepuhan Sinar Resmi.

Imah Gede telah mengalami beberapa kali perombakan atau direhab, awalnya rumah ini merupakan imah panggung biasa tanpa kaca, berlantai talupuh, dan semuanya bertiang bambu. Namun setelah Abah Ujat diangkat menjadi tutunggul, perubahan rumah segera dimulai oleh Abah Ujat, disusul oleh Abah Arjo dan diteruskan oleh Abah Asep. Sepeninggalnya Abah Arjo, perubahan yang terjadi yaitu di antaranya adanya penambahan elemen kaca, mempergunakan lantai papan dan menjadi bertingkat. Perubahan yang dilakukan terhadap Imah Gede ini, menurut Abah Asep tidak melanggar tabu, karena Imah Gede yang asli, harus tetap mempergunakan bahan-bahan seperti bertiang bambu, atapnya mempergunakan hateup dan ijuk.

Bumi Rurukan merupakan rumah pokok atau awal dari Imah Gede yang sekarang khusus ditempati oleh keluarga Abah Asep. Seperti yang dikatakan Abah Asep : "Peninggalan imah ieu tos aya nya eta Bumi Rurukan, ngan Abah ngarehab rada digayakeun saalit, atapna julang ngapak nu asalna jingjing renggis". Setelah adanya rehab atau perbaikan yang dilakukan oleh Abah Asep, Imah Gede menjadi lebih besar dan lebih estetik dan beratap dengan gaya julang ngapak.

Selanjutnya Abah Asep mengatakan: "Sataun ti karam timbul taun 2003 ngarehab rurukan, awi sadayana, anu husus ti pengker. Taun 2006 ngarehab Imah Gede nu payun, biayana ngajengkeun ka pamarentah. Dina Imah rurukan aya istilah hateup salak tihang cagak, nu hartina imah sederhana nu penting teu ngaleungitkeun fungsi nu aya dina rurukan, 'dipen' atanapi dipaseuk ditalian ku hoe teu aya paku. Nu kedah aya, hateup kiray,jeung injuk. Imah Gede mah tiasa bebas tina kayu, hateup, injuk keur Imah Gede ku Abah Arjo mah ya paku" (Satu tahun setelah pergantian, pada tahun 2003 diawali dengan perbaikan rurukan, yaitu rumah bagian belakang, semuanya harus berbahan bambu. Tahun 2006 dilanjutkan dengan perbaikan Imah Gede yaitu rumah bagian depan. Biayanya mengajukan kepada pemerintah. Dalam Bumi Rurukan ada istilah hateup salak tihang cagak, artinya rumah harus sederhana yang penting tidak menghilangkan fungsinya. Harus menggunakan pen atau paseuk (paku dari kayu) atau diikat dengan tali rotan. Yang harus ada atap kiray, dan ijuk. Sedangkan oleh Abah Arjo dimungkinkan penggunaan paku).

Sudah dua kali terjadi perubahan Imah Gede ini, pertama pada tahun 2003 setelah karam timbul --karam berarti meninggal, timbul berarti muncul yang baru mengganti yang lama, artinya ketika Abah Arjo meninggal dan kemudian digantikan oleh Abah Asep-- merombak Bumi Rurukan semuanya. Kemudian pada tahun 2006 merombak Imah Gede secara keseluruhan. Rumah yang tadinya berukuran kecil, kini ukuran rumah diperlebar menjadi $9 \mathrm{~m}$ x $24 \mathrm{~m}$. Hal ini diperlukan karena semakin bertambahnya incu putu yang ada di luar Kampung Sinar Resmi, agar rumah ini dapat menampung semua incu putu Abah Asep dalam acara ritual adat pada waktu-waktu tertentu.

\section{O rganisasi Imah Gede}

Organisasi rumah Imah Gede berbeda dengan organisasi rumah penduduk pada umumnya. Imah Gede memiliki berbagai ruangan yang tidak ada pada rumah penduduk, seperti taweuran berada di depan rumah, tepas dan kamar tidur tamu, tengah imah, Bumi Rurukan, dapur, pangdaringan, goah, pangbeasan, panyimpenan sayur, para, hawu para 
seuneu, kamar kerja abah, kamar tidur abah.

Taweuran, adalah tempat yang sangat berfungsi, karena bukan saja sebagai tempat ngalayung pasosore, ngadaweung, nampi tamu (bercengkerama sore-sore, bercengkerama dengan tetangga, tempat menerima tamu, tempat bermain anak-anak, juga tempat untuk bersantai pada sore hari), selain itu taweuran merupakan ciri estetika 'artifisial' Imah Gede.

Tepas merupakan ruangan yang letaknya di depan, fungsinya untuk menerima tamu. Di samping itu, ruangan ini secara kosmologis memiliki fungsi untuk menyaring 'filter' dari hal-hal atau pengaruh yang bersifat kotor masuk ke dalam imah. Di samping itu secara kosmologis tepas merupakan ruangan kekuasaan laki-laki. Bila rumah yang tidak memiliki tepas, biasanya ruangan filter itu ditempatkan pada taweuran. Ruangan tepas Imah Gede dibuat dengan ukuran yang sangat luas, fungsinya untuk menampung tamu yang datang atau berfungsi untuk melakukan berbagai acara ritual adat. Di dalam ruangan tepas ini terdapat beberapa ruang kamar tidur yang sengaja pula disediakan untuk tamu-tamu kehormatan. Di ruang tepas ini, biasanya Abah menerima tamu dan berbincangbincang dengan mereka baik yang datang sekadar bertamu maupun para peneliti, mahasiswa atau aparat pemerintah.

Selain itu, tepas biasanya dipergunakan untuk melakukan berbagai kegiatan acara ritual yang secara berkala dilakukan di Kampung Sinar Resmi. Acara ritual yang berkaitan dengan proses pertanian diawali di Imah Gede, khususnya dari ruang tepas ini, seperti acara ngaseuk, nganyaran, ngadiukeun, dimulai dari ritual di Imah Gede. Begitu pula dengan ritual yang berkaitan dengan adat lainnya, seperti acara perkawinan, ngabeberes orang yang berbuat salah secara adat, mengadakan musyawarah kokolot lembur, dan lain-lain.

Tamu yang dianggap sudah menjadi warga atau lebih dekat dengan Abah biasanya diterima dan berkumpul di tengah imah, begitu pula dengan incu putu yang datang dari berbagai pelosok mereka langsung memasuki ruang tengah imah dan bercengkerama dengan Abah. Namun bila mereka ingin berbicara secara khsusus biasanya diajak ke ruang khsusus di Bumi Rurukan.

\section{Fungsi Rumah}

Rumah bagi masyarakat Kampung Sinar Resmi dalam kesehariannya dapat berfungsi sebagai:

a. Tempat menyimpan bahan makanan yaitu dengan adanya goah dan pangdaringan di dalam rumah. Di samping itu, rumah dapat pula sebagai tempat pembuat dan yang menyediakan makanan, dengan adanya hawu.

b. Tempat untuk menerima tamu di ruang tepas. Pada upacara daur hidup, misalnya sunatan atau kawinan dan melahirkan banyak tamu atau keluarga dari luar Kampung Sinar Resmi yang datang bertandang. Mereka datang dan diterima di tepas kemudian menyimpan perbekalannya ke dapur.

c. Tempat bekerja dalam menambah penghasilan dan mata pencaharian tambahan.

d. Tempat istirahat, tidur dan meneruskan keturunan dengan adanya ruang kamar.

e. Dalam lingkup yang lebih jauh, imah dapat berfungsi sebagai tempat upacara atau salametan daur hidup mulai dari kehamilan, kelahiran, perkawinan sampai kematian.

\section{Makna dan Simbolik A rsitektur Rumah}

Sistem pembagian ruangan pada rumah tempat tinggal berhubungan dengan pandangan masyarakat tentang kedudukan dan fungsi masing-masing anggota keluarga penghuni suatu rumah. Pembagian itu didasarkan pada tiga daerah yang terpisah dibedakan penggunaannya, 
yaitu: daerah wanita, daerah laki-laki, dan daerah netral.

Pembagian fungsi ruangan ini memang tidak begitu kentara, namun ketika ruangan itu dibuka untuk difungsikan, maka ada pembagian khusus. Dalam penggunaannya orang tidak dapat sembarangan untuk memasukinya. Demikian pula ketika seorang laki-laki dilarang memasuki daerah pangdaringan/goah 'lumbung tempat menyimpan beras' akan sangat berkaitan dengan kepercayaan yang sakral.

Dalam Imah Gede, memiliki simbolsimbol Tritangtu yang dapat dilihat dalam beberapa aspek seperti yang diuraikan di bawah ini:

a. Tihang (tiang) mempunyai makna ajegna kahirupan (tegar dan tegaknya kehidupan).

b. Bilik yang dipasang di empat penjuru, menunjukkan opat kalima pancer, diwatek tina opat dina kahirupan (bilik yang dipasang di tengah rumah di keempat sisi rumah).

c. Sungsuhunan nu segi tilu sama sisi, urang teh kudu ngajaga ucap, ngajaga tekad, jeung laku lampah, kudu bisa ngaulaan nagara, mokaha oge nyanghulu ka hukum, nunjang ka nagara, mupakat jeung balarea. (Atap yang menyerupai segitiga sama sisi artinya harus menjaga ucapan, tekad, dan perilaku, harus hormat kepada negara, hukum, dan bermufakat).

d. Teras nu buleudna, ngabogaan makna kabuleudan tekad urang di mana-mana hirup atawa wih teh pasti ka mana. (Bentuk $\mathrm{O}$ di atas atap memiliki makna kebulatan tekad, walaupun kita berada di mana saja, pasti akan kembali ke haribaanNya).

e. Tihang (tiang) yang ditopang oleh bilik yang ada di keempat sudut wetan, kidul, kulon, kaler (timur, selatan, barat dan utara) menandakan makna kehidupan yang kuat.

f. Siku-siku sebagai peneguh dan penguat tiang kehidupan atau keajegan hidup. Menurut Abah, dengan keajegan ini kita akan "Apal kanu hirup, apal kanu ngahirupanana. Apal kanu cicing, apal kanu nyicingkeunana, aya dina raga badag urang. Nu aya di badan awaking. Cageur bageur, hirup tetep tumaninah, tiis ceuli herang mata, subur makmur loh jinawi, rea ketan, rea keton, murah sandang murah pangan, hirup aing salamet dunya aherat.

Tos ngadeg kitu urang deukeut jeung nu kagungannana Dina jawa mah manunggaling gusti, dina Sunda mah Nganti ka gusti ngaraga jeung nu kawasa.eta harti buleud tea". (Mengerti hidup, kenal kepada yang menghidupi, mengerti diam dan kenal kepada yang mendiamkan, semua ada dalam diri kita. Sehat dan bageur, hidup tenang tidak ada gosip, subur murah sandang murah pangan, hidup harus selamat di dunia dan akhirat).

Rumah milik masyarakat Kasepuhan Sinar Resmi memiliki tata ruang sebagai berikut; tengah imah, kamar (kamar tidur), dapur, dan goah. Ruang tengah imah dan kamar merupakan satu kesatuan, karena berada di ruang depan sebuah rumah. Sedangkan goah dapat dikatakan sebagai ruang utama dalam sebuah rumah, karena goah sama artinya dengan pabeasaan yaitu tempat menyimpan beras sebagai bahan makanan. Penempatan ruang - ruang tersebut antara dapur, parako atau tungku dan goah merupakan satu kesatuan yang tidak dapat dipisahkan sehingga ditempatkan di depan, dibanding dengan kamar tidur yang berada di belakang goah atau dapur.

Rumah, permukiman dan seluruh buatan manusia dapat menggambarkan nilai budayanya, karena pembentukan ruang pada dasarnya merupakan 
manifestasi dari budaya masyarakat dalam bentuk lingkungan binaan 'build form'. Pembentukan ruang juga merupakan refleksi dari struktur sosial (Strauss, 1963 dalam Sasongko, 2006). Hirarki ruang ini akan tertuang dalam berbagai skala, tetapi pada umumnya ada dalam skala rumah, kumpulan rumah, lingkungan permukiman, hingga skala desa (Haryadi dan Setiawan dalam Sasongko, 2006).

Rumah memiliki arti yang sangat spesifik. Dalam bahasa Sunda lemes 'halus' rumah berarti bumi artinya dapat beranalogi sebagai jagat alam semesta yang menampung berbagai aspek kehidupan di dalamnya. Pengertian rumah atau bumi menuntut kesadaran yang penuh tanggung jawab dari orang sebagai penghuninya. Hal tersebut dapat dilihat dari aturan yang digariskan oleh karuhunnya dalam tata cara mendirikan rumah, begitu pula penempatan ruangruang yang ada di dalamnya harus sesuai dengan tatali karuhun yang seharusnya. Pembangunan dimulai pada hari yang telah ditentukan dan dipandang sebagai hari baik bagi si pemilik rumah, dalam membangun rumah bagi si anak atau si adik, tidak boleh berada di sebelah timur, karena akan ngalangkangan 'membayangi' rumah orang tua atau kakaknya, bila hal itu dilanggar maka akan mengakibatkan bencana. Dalam praktiknya belum pernah ada pembangunan rumah seperti itu. Dalam pengorganisasian ruang-ruang dalam rumah pun harus ditaati selaras tata aturan tatali karuhunnya, walaupun perubahan demi perubahan terus terjadi dan berlanjut dari hari ke hari. "Boleh terjadi perubahan namun hal-hal pokok tidak boleh dirempak atau 'dilanggar',

Rumah identik dengan 'dunia' yang lebih besar. namun demikian, rumah secara keseluruhan bagi orang Sunda dapat dipandang memiliki sifat kewanitaan. Hal ini dapat diamati dengan adanya ucapan kumaha nu di imah 'bagaimana istri saja' yang sering diungkapkan oleh seorang suami. Ungkapan tersebut tercermin bagaimana peranan seorang wanita atau istri yang sangat menentukan di rumah, istri sebagai tuan di rumah.

Secara kosmologis, kamar tidur, merupakan wilayah wanita, karena biasanya wanita biasa melahirkan di dalam kamarnya sendiri dibantu oleh ma beurang atau ma paraji 'dukun beranak'. Proses kelahiran yang dilakukan di kamar inilah kemudian menjadi geusan 'tempat awal' kelahiran seseorang. Dalam paribahasa Sunda 'ungkapan tradisional Sunda' ada yang dikatakan bali geusan ngajadi 'plasenta merupakan awal terjadinya manusia' yang menunjukkan bahwa manusia dilahirkan di tempat itu. Ungkapan bali geusan ngajadi adalah ungkapan untuk mengingatkan seseorang kepada awal proses manusia, atau secara fisik adalah tempat di mana ia dilahirkan.

Dapur, pangdaringan dan goah, merupakan tempat yang istimewa. Elemen dapur yang harus dipenuhi sesuai dengan tatali karuhun adalah tungku, palupuh, parako dan goah. Hal tersebut mengalahkan penempatan kamar tidur si pemilik rumah. Dapur, dan goah adalah pusat kehidupan manusia yang harus dijaga sesuai dengan sistem kepercayaannya. Goah adalah unsur yang penting dalam kehidupan kesehariannya. Wilayah kedua tempat ini, yaitu dapur dan goah adalah wilayah wanita yang tidak sembarang orang bisa memasukinya. Khususnya ruang pangdaringan, hanya kaum wanitalah yang bisa memasukinya, di ruangan ini Kersa Nyai 'Nyi Pohaci' atau Nyi Pohaci Sang Hyang Sri Dangdayang Tisnawati 'Dewi Sri' ditempatkan.

Pengaturan tata ruang tradisional Sunda, tidak terlepas dari tritangtu, yaitu sistem pengetahuan yang tercermin dari kosmologinya. Pada awal waktu ditetapkan, maka dilakukan hajatan untuk meminta restu karuhun dan agar terhindar dari pengaruh kekuatan-kekuatan yang dianggap buruk. Dengan demikian, pengetahuan tentang tata ruang dalam pandangan manusia Sunda tampak dengan jelas memadukan konsep dunia gaib 
dengan dunia manusia yang menjelma kontras, tetapi saling mengisi antara dunia laki-laki, dunia wanita dan dunia keduanya (laki-laki dan wanita).

Begitu pula secara spiritual; tri tangtu (Atja, 1981) digambarkan dalam bentuk bangunan rumah Sunda yang biasanya berbentuk panggung. Berdasarkan pandangan kosmisnya, kedudukan secara makro dalam jagat raya ini terletak di antara dunia bawah dan dunia atas, maka dengan demikian rumah berada di daerah netral yang merupakan penghubung di antara dua dunia tadi.

Konsep dasar pembagian ruang pada rumah tradisional Sinar Resmi, berlaku klasifikasi tiga, yaitu ruang tepas 'depan', tengah rumah, dan ruang belakang; terdiri atas ruang pangdaringan 'tempat menyimpan beras' dan dapur. Di antara kedua ruang tersebut ada ruang pemisah atau ruang antara, yaitu tengah rumah 'ruang tengah' yang berfungsi sebagai ruang penghubung dan lantai atau tataban yang terbuat dari papan dan lantai yang terbuat dari talupuh. Tepas adalah ruang laki-laki, berfungsi sebagai tempat menerima tamu, walaupun wanita boleh masuk ke ruangan ini. Ruang tengah imah 'tengah rumah' merupakan daerah netral digunakan untuk berkumpul seluruh anggota keluarga, mereka berbaur di tempat ini, dan berfungsi pula sebagai penghubung antara ruang tepas 'depan' dengan ruang belakang 'dapur'. Ruang kamar 'kamar tidur', merupakan kategori daerah wanita dan sangat dominan menggambarkan ciri kewanitaan. Siapa pun dilarang masuk ke dalam ruangan ini, kecuali suami istri. Ruang tidur ini biasanya terletak di sebelah kanan agak menyudut dari arah kamar. Secara struktural letaknya agak menjauh dari ruang pangdaringan dan ruang tamu yang biasanya terletak di daerah tepas atau tengah imah yang agak menjorok ke arah sudut kiri.

Konsep pembagian tiga terhadap ruang-ruang rumah dan halaman menjadi daerah laki-laki dan daerah wanita yang dibatasi oleh ruang/daerah netral itu, harus dilihat sebagai kategorisasi yang bersifat ritual dan fungsional. Misalnya laki-laki secara adat tidak boleh masuk ke dalam pangdaringan, karena ruang tersebut hanya diperuntukkan bagi kaum wanita. Daerah pangdaringan identik dengan Dewi Sri, 'dewi padi' yang memiliki sifat kewanitaan. Makhluk-makhluk halus (dedemit, jurig, ririwa, kelong) yang bertalian dengan dunia di luar rumah, cenderung bersifat laki-laki dan dengan demikian harus dihadapi oleh laki-laki pula.

Bentuk bangunan rumah Sunda biasanya berbentuk panggung, berdasarkan pandangan kosmisnya, kedudukan secara makro dalam jagat raya ini terletak di antara dunia bawah dan dunia atas, maka dengan demikian rumah berada di daerah netral yang merupakan penghubung di antara dua dunia tadi. Manifestasi rumah panggung tadi, mengingatkan kita pada saung ranggon yang tingginya mencapai 4 meter, menunjukkan bahwa manusia Sunda adalah peladang (ladang = huma) di mana arti imah identik dengan huma (Rusnandar, 2000) .

Perlu dijelaskan di sini, meskipun telah diungkapkan bahwa rumah itu mengandung daerah laki-laki dan daerah wanita secara jelas, namun dalam cara memandang rumah itu dengan unit-unitnya yang lain bergantung pula pada konteksnya. Jadi dalam beberapa hal dapat pula dipandang rumah itu memiliki sifat laki-laki dan wanita, tetapi dalam konteks yang lain dapat bersifat salah satu.

Rumah, secara makro merupakan lambang kewanitaan, terlihat dalam tata cara mewariskan rumah, di mana rumah tersebut jatuhnya kepada anak wanita dan atau kepada menantu wanita. Begitu pula dalam tata cara membangun rumah dan pindah memasuki rumah baru, biasanya perhitungan hari baik/buruk didasarkan pada hari kelahiran istrinya yang akan membangun rumah, sehingga pembangunan rumahnya dimulai dengan membangun pangdaringan. 


\section{PEN UTU P}

Untuk mengetahui perkembangan arsitektur, kita perlu mengkaji perjalanan sejarah bangsa dan perjalanan sejarah manusia itu sendiri. Dari perjalanan ini pula kita akan mengetahui fungsi arsitektur secara hakiki. Di samping itu, pengaruh alam sekitar memberikan corak dan ragam bagi perkembangan arsitektur daerahnya. Apabila kita menelaah lebih jauh mengenai suatu bentuk bangunan, maka sebaiknya didahului dengan beberapa catatan tentang berbagai ciri gaya bangunan yang berlaku pada waktu tertentu. Gaya bangunan itu ialah suatu cara membangun dengan menggunakan bahan yang dipilih dari kekayaan bahan yang sudah tersedia, atau hanya sedikit memerlukan pengerjaan. Karenanya bahan itu untuk sebagian besar berupa bahan-bahan yang disediakan alam sendiri dan dalam keadaan siap pakai. Bahan ini adalah yang paling dahulu memberikan perlindungan yang mereka butuhkan. Dengan berlalunya waktu, maka manusia (masyarakat) itu menemukan bentuk-bentuk bangunan yang menurut pengalamannya (empirik) merupakan perwujudan idealnya yang paling baik.

Dalam kajian arsitektur tradisional, kita perlu memahami secara mendalam tentang masyarakat dan budayanya, karena hal tersebut merupakan subjek yang sangat penting. Hal itu disebabkan bahwa Arsitektur selalu berkaitan dengan konteks budaya di mana arsitektur itu berada. Perubahan budaya sekecil apapun yang menimpa masyarakatnya, maka arsitektur pun akan ikut berubah. Sejarah membuktikan bahwa budaya dan arsitektur selalu membuka diri pada proses perkembangan yang datangnya dari luar. Budaya dan arsitektur pada dasarnya tidak pernah statis, melainkan dinamis sepanjang masa yang selalu menyesuaikan diri dengan situasi dan kondisi masyarakatnya.

Demikian pula yang terjadi dengan perkembangan arsitektur rumah, rumah pada mulanya hanya dibangun sebagai pelindung terhadap elemen cuaca yang mengganggu (terik, hujan, angin, dan lain- lain) dan binatang buas, seperti manusia purba, mereka hanya menempati gua-gua alam. Kemudian berkembang tidak saja menempati gua tapi mencoba mepergunakan bahan-bahan alam yang ada di sekitarnya. Pada tahap ini, elemen rumah yang dibutuhkan hanya berupa atap dan dinding yang bersifat darurat dari bahan-bahan yang langsung bisa didapat dari alam secara mudah. (daun besar, gua, dahan yang tergantung rendah, dan lainlain) Setelah manusia mengenal aktivitas yang bersifat menetap (bercocok tanam, berternak, dan berburu) maka bentuk rumah pun ikut berkembang. Kondisi alam secara langsung akan memengaruhi perilaku manusia yang tinggal, dan secara fisik terhadap bentuk arsitekturnya yang terbentuk di daerah itu. Pada keadaan tertentu, arsitektur juga dapat memengaruhi perilaku manusia yang tinggal dan sebaliknya.

Rumah bagi masyarakat Kasepuhan Sinar Resmi dalam kesehariannya dapat berfungsi sebagai tempat menyimpan bahan makanan yaitu dengan adanya goah dan pangdaringan di dalam rumah. Selain itu imah berfungsi sebagai tempat istirahat, tidur dan meneruskan keturunan dengan adanya ruang pangkeng atau geusan. Dalam lingkup yang lebih jauh, imah dapat berfungsi sebagai tempat upacara atau selamatan daur hidup mulai dari kehamilan, kelahiran, perkawinan sampai kematian.

Pembangunan sebuah rumah tak lepas dari ritus yang secara adat selalu dipatuhi dan dilaksanakan dengan benar, hal tersebut sangat erat kaitannya dengan sistem kepercayaan yang mereka anut. Kenapa hal itu dilaksanakan, karena mereka takut akan melanggar pamali. Demikian pula rumah dan pola perkampungan yang ada di Kasepuhan Sinar Resmi erat hubungannya dengan alam sekitar, sehingga rumah dapat dianalogikan sebagai 'mikro kosmos' atau bumi 'makrom kosmos' yang berarti alam semesta. 
Beberapa perubahan yang terjadi pada pembangunan rumah diawali oleh Abah Ujat dan diteruskan oleh Abah Asep Nugraha, sehingga rumah terlihat lebih fungsional. Perubahan yang terjadi dapat dilihat dalam tabel di bawah ini:

\begin{tabular}{|c|c|}
\hline & \\
\hline $\begin{array}{l}\text { Bahan rumah: } \\
\text { material bam- } \\
\text { bu dan kayu. }\end{array}$ & $\begin{array}{l}\text { Bahan rumah: adukan } \\
\text { semen dan berlantai } \\
\text { keramik. }\end{array}$ \\
\hline $\begin{array}{l}\text { hateup, } \\
\mathrm{uk}\end{array}$ & $\begin{array}{l}\text { Atap: genting, asbes } \\
\text { walaupun hateup masih } \\
\text { menjadi ciri khasnya. }\end{array}$ \\
\hline $\begin{array}{l}\text { Bentuk atap: } \\
\text { jingjing reggis }\end{array}$ & $\begin{array}{l}\text { Bentuk atap: julang } \\
\text { ngapak }\end{array}$ \\
\hline $\begin{array}{l}\text { Dinding } \\
\text { rumah: bilik } \\
\text { tanpa dikapur } \\
\text { atau dicat }\end{array}$ & $\begin{array}{l}\text { Dinding rumah: papan, } \\
\text { dikapur dan dicat. }\end{array}$ \\
\hline $\begin{array}{l}\text { Jendela: satu } \\
\text { jendela }\end{array}$ & $\begin{array}{lr}\text { Jendela: memiliki } \\
\text { variasi } \\
\text { mempergunakan kaca }\end{array}$ \\
\hline $\begin{array}{l}\text { Rumah } \\
\text { memiliki satu } \\
\text { lantai }\end{array}$ & $\begin{array}{l}\text { Rumah memiliki dua } \\
\text { lantai (loteng). }\end{array}$ \\
\hline $\begin{array}{l}\text { Tataban } \\
\text { semuanya } \\
\text { lantai rumah } \\
\text { terbuat dari } \\
\text { talupuh }\end{array}$ & $\begin{array}{l}\text { Tataban hanya bagian } \\
\text { dapurnya saja yang } \\
\text { terbuat dari talupuh, } \\
\text { tengah imah sudah } \\
\text { mempergunakan lantai } \\
\text { dari papan yang diserut } \\
\text { rapih. }\end{array}$ \\
\hline $\begin{array}{l}\text { Kolong: } \\
\text { tempat untuk } \\
\text { kandang } \\
\text { ternak }\end{array}$ & $\begin{array}{l}\text { Kolong: tidak lagi } \\
\text { menjadi kandang } \\
\text { ternak, sesuai dengan } \\
\text { kesadaran akan nilai- } \\
\text { nilai kesehatan }\end{array}$ \\
\hline $\begin{array}{l}\text { knologi: } \\
\text { gat } \\
\text { lerhana } \\
\text { ak } \\
\text { ngenal } \\
\text { ku. }\end{array}$ & $\begin{array}{l}\text { Teknologi: mengenal } \\
\text { paku }\end{array}$ \\
\hline $\begin{array}{l}\text { Non- } \\
\text { elektronik }\end{array}$ & . \\
\hline $\begin{array}{l}\text { Tungku: hawu } \\
\text { yang terbuat } \\
\text { dari tanah. }\end{array}$ & $\begin{array}{l}\text { Tungku: hawu } \\
\text { kompor gas. }\end{array}$ \\
\hline
\end{tabular}

\section{DAFTAR SU MBER}

Adimihardja, Kusnaka et al. 1981. Tipe Rumah Tradisional Khas Sunda Jawa Barat. Kanwil Direktorat Jenderal Pariwisata Jawa Barat.

Atja, dan Saleh Danasasamita. 1981. Naskah Sanghyang Siksakandang Karesian. Proyek Pengembangan Permusiuman Jawa Barat. Bandung.

Belgawan, Ismet dan Nandang Rusnandar. (ed.). 2011.

Arsitektur Rumah dan Permukiman Tradisional di Jawa Barat. Provinsi Jawa Barat. Dinas Pariwisata dan Kebudayaan.

Egenter, Nold. 1991. "Architectual Anthropology : Why do wee need a General Framework?" Second International Conference of the International Association for the Study of Traditional Environments, University of California. Berkeley. Oct. 4-7.

Koentjaraningrat. 1981. Kebudayaan, Mentalisme dan Pembangunan. Jakarta. Gramedia.

Oliver, Paul. 1987.

Dwelling-The Houses Across the World. Phaidon Press Limited.Oxford.

1997. Encyhclopedia of Vernacular Architecture of The World, Cambridge University Press, Vol. 1, United Kingdom.

Mulyana, Deddy. 2001 Metodologi Penelitian Kualitatif. Paradigma Baru Ilmu Komunikasi dan Ilmu Sosial Lainnya. Bandung: Remaja Rosdakarya.

Rapoport, A. 1990.

"Defining Vernacular Design" dalam Turan, M. (ed) Vernacular ArchitectureParadigms of Environmental Response, Averbury, Gower Publishing Company, Ltd., London.

Rusnandar, Nandang 2010.

Arsitektur Rumah Adat Tradisional Kampung Naga. Bandung: Balai Kajian Sejarah dan Nilai Tradisional Bandung. 
2003.

Saung Ranggon Sebuah Karya Arsitek

Tradisional. Bandung: Balai Kajian Sejarah dan Nilai Tradisional Bandung.

Suganda, Her . 2006

Kampung Naga Mempertahankan Tradisi. Bandung: Kiblat.

Suhamihardja, Suhandi A., Yugo Sariyun. 1991/1992.

Kesenian, Arsitektur Rumah dan Upacara Adat Kampung Naga, Jawa Barat. Jakarta: Proyek Pembinaan Media Kebudayaan, Ditjen Kebudayaan, Depdikbud.

Sumintardja, Djauhari. 1978.

Kompedium Sejarah Arsitektur. Yayasan Lembaga Penyelidikan Masalah Bangunan. Jl. Tamansari Bandung.

Turan, M. 1990.

"Vernacular Design and Environmentas Wisdom" dalam Turan, M. (ed.) Vernacular Architecture-Paradigms of Environmental Response. Averbury, Gower Publishing Company, Ltd., London. 